\title{
PENTA POLITIKA INDONESIA DALAM PERSPEKTIF SEJARAH PERADABAN MASA LALU DAN MASA KINI
}

\author{
Umi Salamah \\ IKIP Budi Utomo \\ yumasumi1908@gmail.com
}

\begin{abstract}
Abstrak
Founding Father negara Indonesia memberikan contoh bagaimana menghargai sejarah peradaban bangsa sendiri seiring kemajuan ilmu pengetehuan dan teknologi dalam merumuskan landasan kenegaraan dan citacita kemerdekaan. Sejarah kejayaan dan keruntuhan peradaban bangsa digunakan sebagai tata buku masa lalu dalam menyusun rencana pembangunan peradaban bangsa di masa depan agar kedaulatan politik, kemandirian ekonomi, dan kepribadian yang berbudaya kuat, berdaulat, dan bermartabat. Sebagai salah satu bukti, bahwa peradaban bangsa Indonesia di masa lalu lebih maju dari bangsa Eropa adalah ditemukannya prasasti konsep pemilahan kekuasaan sejak Abad-12, sementara di Eropa digaungkan dalam tulisan John Locke dan Montesquieu mulai akhir Abad 17. Carut-marutnya, perpolitikan di negara Indonesia saat ini, lebih disebabkan oleh pemahaman yang dangkal para elit politik terhadap substansi sejarah peradaban dan budaya masa lalu yang telah dirumuskan oleh para pendiri bangsa Indonesia dalam cita-cita Proklamasi 17 Agustus 1945, Preambule UUD 1945, Batang Tubuh UUD 1945, dan ideologi Pancasila. Para elit enggan mengkaji substansi nilai-nilai dan pesan yang terkandung dalam dokumen tersebut. Mereka lebih suka "Membeli Produk Instan" peradaban luar negeri demi kepentingan pribadi dan kelompoknya. Tidak mengherankan jika pragmatisme politik, produk Barat itu lebih berkembang daripada tata berpolitikyang beretika sebagaimana yang dilakukan oleh para leluhur kejayaan Nusantara dan para pendiri bangsa. Prinsip yang harus dipegang kuat adalah ketika belajar dari peradaban bangsa lain bukan berarti menghilangkan eksistensi budaya sendiri.
\end{abstract}

Kata kunci: Landasan kenegaraan, Penta Politica, tata buku masa lalu, amandemen UUD 1945

\section{PENDAHULUAN}

Selama ini, bangsa-bangsa di dunia mengenal Trias Politica yang dikemukakan oleh John Locke yang kemudian disempurnakan oleh Montesquieu pada Abad 17 sebagai produk teori modern demokrasi Barat pertama yang memilah wewenang dan tugas kekuasaan politik pemerintahan. Trias Politica dilatari oleh zaman kegelapan di Eropa, ketika kekuasaan politik menjadi persengketaan antara Monarki (raja/ratu), pimpinan gereja, dan kaum bangsawan. Kerap kali Eropa kala itu dilanda perang saudara sebagai akibat sengketa kekuasaan antara tiga kekuatan politik ini. Sebagai koreksi atas ketidakstabilan politik ini, pada abat-17 muncul semangat baru di kalangan intelektual Eropa untuk mengkaji ulang filsafat politik yang bertujuan melakukan pemisahan kekuasaan (Busroh, 2010).

Ajaran Trias Politica memiliki pengaruh yang sangat luas di abad XVIII-XX, baik di benua Eropa, Amerika, maupun Afro-Asia. Meskipun demikian, para pendiri bangsa Indonesia tidak begitu saja mengadopsi Trias 
Politica dalam konsep pembagian kekuasaan dalam pemerintahan di Republik Indonesia karena Indonesia memiliki sejarah peradaban yang berbeda dengan Eropa.

Penta Politica merupakan konsep pemisahan kekuasaan yang digagas oleh pendiri negara berdasarkan kajian keunggulan budaya masa lalu berdasarkan kemajuan ilmu pengetahuan. Penta Politica yang dipopulerkan oleh Uttunggadewa dalam bukunya Negara Gotong Royong (2015) menunjukkan bahwa pemikiran Founding Father terhadap pemilahan fungsi dan tugas lembaga tinggi negara didasarkan pada kajian tata pemerintahan kejayaan peradaban masa lalu dengan cara pandang masa kini, merupakan pemilahan kekuasaan yang paling cocok dalam konteks ke-Indonesiaan. Penta Politica tersebut selanjutnya diatur dalam batang tubuh UUD 1945.

Carut-marutnya, perpolitikan di negara Indonesia saat ini disebabkan oleh pemahaman yang dangkal oleh para elit terhadap sejarah peradaban dan budaya masa lalu yang telah dirumuskan dalam Preambule UUD 1945, Batang Tubuh UUD 1945, dan ideologi Pancasila. Para elit enggan mengkaji substansi nilai-nilai dan pesan yang terkandung dalam dokumen tersebut. Para elit politik lebih suka belajar ke luar negeri "untuk kepentingan golongan dan dirinya" daripada belajar menggali dan memahami keunggulan sejarah peradaban budaya bangsanya sendiri. Tidak mengherankan jika pragmatisme politik, produk Barat itu lebih diminati daripada tata berpolitik yang beretika sebagaimana yang dilakukan oleh para leluhur Nusantara.

Sejarah yang terputus atau adanya kesengajaan diputus oleh para zionis melalui penjajah dari Barat, menjadikan bangsa Indonesia kini gagap dan amnesia terhadap sejarah dan budaya bangsa sendiri. Akibatnya, sebagian besar anak bangsa terombang-ambing oleh globalisasi, krisis jati diri, dan mudah terprovokasi. Itulah salah satu pentingnya pembahasan sejarah Penta Politika yang pernah dimiliki oleh bangsa Indonesia (Djarot, 2006; Salamah, 2017). Artikel ini akan membahas (1) Penta politika dalam perpektif sejarah kebudayaan, (2) Penta politika dalam perpektif kekinian.

\section{PEMBAHASAN}

\section{Penta Politika dalam Perspektif Sejarah Peradaban Masa Lalu}

Founding Father Indonesia, tidak pernah gegabah apalagi serampangan dalam merumuskan landasan kenegaraan. Cita-cita Proklamasi 17 Agustus 1945, Preambule UUD 1945, sila-sila dalam ideologi Pancasila, dan pasal-pasal dalam batang tubuh UUD 1945 merupakan landasan kenegaraan, yang benar-benar dikaji dari keunggulan dan kejayaan peradaban kebudayaan nusantara sebagai tata buku masa lalu disesuaikan dengan perkembangan ilmu pengetahuan dan teknologi.

Pada dasarnya landasan kenegaraan adalah landasan filosofi sebuah negara dan menjadi tolak ukur pembuatan kebijakan/kontrak masyarakat yang dibuat oleh Pemerintah. Contoh sederhana, ketika Pemerintah dan Dewan Perwakilan Rakyat membuat rumusan kebijakan, maka harus menggunakan landasan kenegaraan sebagai tolak ukur untuk mencapai tujuan, kemanfaatan, dan kemaslahatan bagi bangsa dan negara. Oleh sebab itu, hal-hal yang lebih substansial berkaitan dengan landasan kenegaraan haruslah dipahami secara hati-hati oleh para pembuat kebijakan, baik yang berada di pusat ataupun di daerah. Bertolak dari kajian terhadap buktibukti keunggulan peradaban Nusantara Founding Father merumuskan landasan kenegaraan Indonesia, sebagai berikut. 


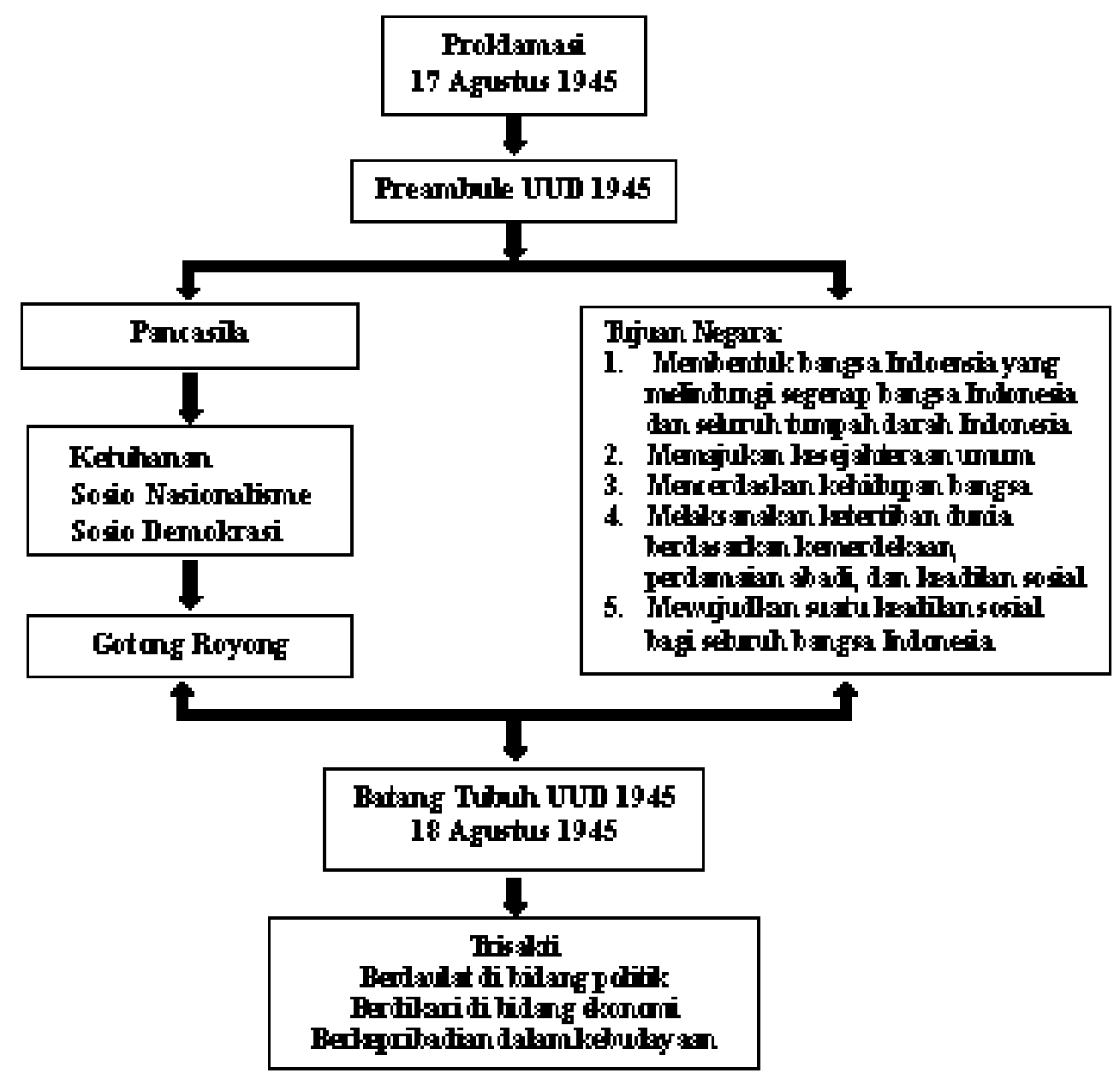

Gambar 1: Landasan Kenegaraan Indonesia (Uttunggadewa: 2015: xvii)

Berdasarkan bagan tersebut, diketahui bahwa landasan tertinggi kenegaraan adalah cita-cita Proklamasi Kemerdekaan 17 Agustus 1945. Kemudian cita-cita tersebut dijabarkan dalam Preambule UUD 1945, tujuan negara yang tertuang dalam batang tubuh UUD 1945. Selanjutnya ditetapkan Pancasila sebagai dasar dan ideologi negara, yang substansinya meliputi, ketuhanan, sosio nasionalisme, dan sosio demokrasi dalam konsep negara gotong royong, dan implementasinya berupa trisakti.

Berdasarkan landasan kenegaraan tersebut, Presiden pertama Indonesia mengisyaratkan bahwa negara Indonesia ini merdeka untuk kedaulatan dan kemakmuran rakyatnya, dengan pemersatu Bhinneka Tunggal Ika dan bahasa Indonesia di dalamnya. Inilah yang mendasari negara Indonesia sebagai Negara Kesatuan.
Berdasarkan azas pemersatu (Bhinneka Tunggal Ika), maka kekuasaan yang berdaulat, adalah kekuasaan yang menjalankan kekuasaan atas kehendak rakyat bukan atas kehendak dari golongan ataupun kelompok.

Mengapa azas ke-Bhinneka Tunggal Ika-an menjadi sangat penting dalam landasan kenegaraan Indonesia? Persatuan merupakan pancer/poros berdirinya dan bertahannya sebuah negara. Tanpa adanya kesadaran untuk bersatu, negara Republik Indonesia tidak akan terbentuk. Belajar dari sejarah kejayaan peradaban bangsa, bahwa Bhinneka Tunggal Ika pernah tertulis dalam beberapa kitab kerajaan nusantara, antara lain dalam kitab Sutasoma dan Kitab Desawarnana yang kemudian oleh Brandes diganti dengan nama Kitab Negara Kertagama (Bratawijaya, 1997). 
Ir. Soekarno ketika masih belajar di SMAN 2 Surabaya, banyak belajar berbagai prasasti Surya Wilwatikta (Majapahit) dan ketika belajar arsitek di Technische Hoogeschool te Bandoeng (sekarang ITB), banyak menggali filsafah kenegaraan di Pa-Ra-Hyangan, Sastra Masyarakat Tatar Jawa Barat, metode yang dimiliki oleh para leluhur Nusantara sejak abad ke-5 yang disebut dengan Sapta Panta Tanda (Kartakusuma, 1991; Hendrawan, 2014). Ini membuktikan bahwa bangsa Nusantara (leluhur Indonesia di masa lalu) sudah memiliki peradaban yang maju, ilmiah, dan beretika.

Belajar dari sejarah peradaban bangsa Nusantara sebagai leluhur bangsa Indonesia, kerajaan-kerajaan Nusantara telah memiliki mesin budaya yang sangat maju di masa-masa kejayaannya, jauh sebelum bangsa Eropa datang ke Nusantara. Sementara itu, bangsa Eropa masih berada pada zaman kegelapan, sebelum datang ke Nusantara ${ }^{1}$. Keunggulan peradaban Nusantara dipotret oleh W.S. Rendra bentuk puisi sebagai berikut.

Wahai, para leluhur Nusantara!

O, Sanjaya!

Leluhur dari kebudayaan tanah!

O, Purnawarman!

Leluhur dari kebudayaan air!

Kedua wangsamu telah mampu

mempersekutukan budaya tanah dan air!

O, Resi Kuturan! O, Resi Nirarta!

Empu-empu tampan yang penuh kedamaian!

Telah kamu ajarkan tatanan hidup

yang aneka dan sejahtera,

yang dijaga oleh dewan hukum adat....

O, Kajao Laliddo! Bintang cemerlang Tana

Ugi!

Negarawan yang pintar dan bijaksana!

Telah kamu ajarkan aturan permainan

di dalam benturan-benturan keinginan

yang berbagai ragam

di dalam kehidupan:

Ade, bicara, rapang, dan wari....

O, Erlangga

Raja tampan bagai Arjuna

Dalam usia 17 tahun
Kau dorong rakyat di desa desa adat Untuk menyempurnakan keadilan hukum adat mereka yang berbeda-beda Dan Lalu kau perintahkan agar setiap adat mempunyai 40 prajurid adat yang menjaga berlakunya hukum adat Sehingga hukum adat menjadi adil, mandiri dan terkawal

\section{Baru kemudian sesudah itu}

Empu Baradah membantumu menciptakan hukum kerajaan

Yang mempersatukan cara-cara kerjasama antara hukum adat yang berbeda beda Sehingga penyair Tantular berseru Bhineka Tunggal Ika ...

Tetapi lihatlah di zaman ini Para elit politik hanya terlatih berjalan-jalan di pasar-pasar tersenyum dan melambaikan tangan sok egaliter

Tetapi egalitarianisme tidak otomatis berarti demokrasi

$\mathrm{O}$, bagaimana mesti aku mengerti

bahasa bising dari bangsaku kini?

(Dibacakan lagi dalam acara "Nasionalisme dan Kebangkitan Ekonomi”, Taman Ismail

Marzuki, Mei 2008).

Gambaran fakta yang dipotret dalam puisi Kesaksian Abad-21 (Salamah, 2017) tersebut menunjukkan bahwa peradaban tata politik di masa lalu lebih beretika daripada saat ini. Tata pemerintahan sudah tertulis sejak dinasti Sanjaya dan Purnawarman Abad ke-5. Tradisi "Blusukan", penegakkan hukum, tata kelautan, tata pertanahan, dan pemisahan kekuasaan sebagai mesin budaya sudah dilakukan oleh para raja Nusantara (leluhur bangsa Indnesia) untuk mewujudkan negara yang adil, makmur, dan berdaulat rakyat. Tradisi tersebut antara lain dikisahkan dalam Kitab Desawarnana karya Empu Prapanca tentang "Blusukan" Raja Erlangga dan Hayam Wuruk (Rendra, 1983). Dalam kitab tersebut, kehadiran raja di daerah-daerah dan desa-desa tidak sekedar "Pencitraan" tetapi benar-benar melihat, memahami, menghayati, mengakomodasi, lalu membuatkan tata perundangan dan peraturan 
untuk kemakmuran dan kedaulatan rakyat.

Puisi W.S. Rendra di atas, memberikan pencerahan untuk membangkitkan kesadaran kolektif bangsa Indonesia bahwa leluhur Nusantara di masa lalu sudah memiliki tata berpolitik yang beretika dan peradaban yang lebih maju dari bangsa Eropa. Mesin budaya peradaban yang sudah maju pernah dimiliki oleh Bangsa Nusantara yang terekam dalam berbagai prasasti, situs, artefak, dan kitab-kitab kuno, ratusan tahun sebelum ditulis oleh bangsa Barat. Itu menunjukkan bahwa leluhur bangsa Indonesia sebenarnya merupakan bangsa pelopor bukan bangsa pengekor.

Sebagai contoh, pemisahan kekuasaan yang di Eropa baru diluncurkan pada akhir abad 17, sudah dimiliki oleh leluhur bangsa Indonesia, yang antara lain tergambar dalam lambanglambang kerajaan, di antaranya pada Surya Wilwatikta.

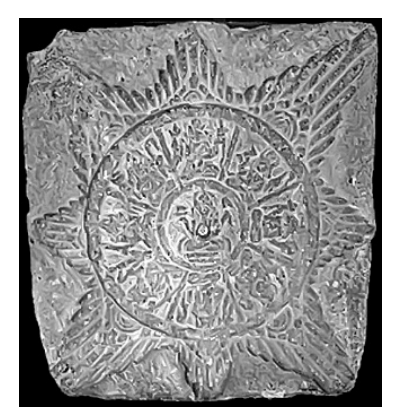

\section{Gambar 1: Lambang ke-2 Suya Wilwatikta/ Surya Majapahit}

Lambang Surya Wilwatikta (oleh Brandes diterjemahkan menjadi Majapahir) dibuat pada masa pemerintahan Ratu Ke-3: Sri Tribhuwana Tunggadewi Maharajasa Jayawisnu Wardhani atau Dyah Gitarja. Lambang tersebut dibuat dari kesadaran bahwa sejarah kelam pemberontakan di era kepemimpinan kakaknya, membuat Beliau merombak total sistem kenegaraan yang ada. Beliau mengadopsi pemikiran kakeknya (Raja Singhasari: Sri Kertanegara), yang dibantu oleh para bibi sekaligus ibunya (4 putri Sri Kertanegara) untuk merumuskan arah baru dari kebijakan politis negara. Beliau menyadari bahwa, pertikaian kekuasaan yang pernah terjadi di era Singhasari menjadi pertimbangan utama. Di era inilah kali pertama sebuah kekuasaan dibagi secara merata dan berporos pada poros utama (semacam negara Konfederasi). Ibukota negara dianggap pusat yang paling berkuasa dikawal oleh para raja bawahan. Ditambahkan dengan dua institusi mewakili pondasi negara yang menjaga ajaran agama dan melahirkan pemikiran kenegaraan.

Kekuatan bersenjata yang pernah jaya satu dekade sebelumnya, perannya tidak dikerdilkan tetapi justru dibina dan dikembangkan menjadi lebih besar, dengan cara menyalurkan energi tempur itu secara benar guna melakukan ekspedisi penyatuan dan perlindungan nusantara seperti pemikiran Sri Kertanegara yang sempat tertunda akibat runtuhnya Singhasari dan lahirnya Majapahit. Lambang negara Surya Wilwatikta Ke-2 inilah yang banyak tersebar di seluruh nusantara dan mancanegara sebagai lambang Majapahit (Wilwatikta).

Lambang 8 Dewa yang setingkat menguasai arah dan berporos kepada Dewa Syiwa sebagai penentu utama. Sinar matahari diubah hanya bersudut delapan sesuai arah mata angin. Arah Utara-Timur-Selatan-Barat mempunyai sinaran lebih pendek mempunyai arti raja penguasa arah tersebut (ditinjau dari pusat ibukota) difungsikan sebagai penyangga kekuatan ibukota (kebijakan dalam negeri), sedangkan 4 raja dengan arah lainnya mempunyai sinaran lebih panjang sebagai arah raja yang mengelola manajemen logistik ekspedisi penyatuan nusantara dan perdagangan (kebijakan luar negeri). Pada masa itulah, Majapahit (Wilwatikta) mencapai masa keemasannya. Konsistensi, kerja keras, manajemen tingkat tinggi dan soliditas kepemimpinan yang disebar merata lah kunci utamanya. Lambang ini dipakai oleh 3 (TIGA) orang Raja/Ratu yaitu: Ratu Ke-3 Sri Tribhuwanatunggadewi Maharajasa Jayawisnuwardhani; Raja Ke-4 Sri Tiktawilwa Nagare-swara Sri Rajasanagara 
atau Dyah Hayamwuruk; dan Raja / Ratu Ke-5 Kusumawardhani.

Perubahan simbol pada lambang Surya Wilwatikta menunjukkan bahwa, dalam sejarah peradaban, leluhur Nusantara selalu menggunakan Sejarah sebagai tata buku masa lalu dalam menyusun rencana kemajuan peradapan bangsa di masa depan. Lambang yang mirip dengan Surya Wilwatikta juga pernah dipelajari oleh Bung Karno ketika mengenyam pendidikan di ITB, sebagai lambang kerajaan-kerajaan di wilayah Pajajaran yang bentuknya berikut ini.

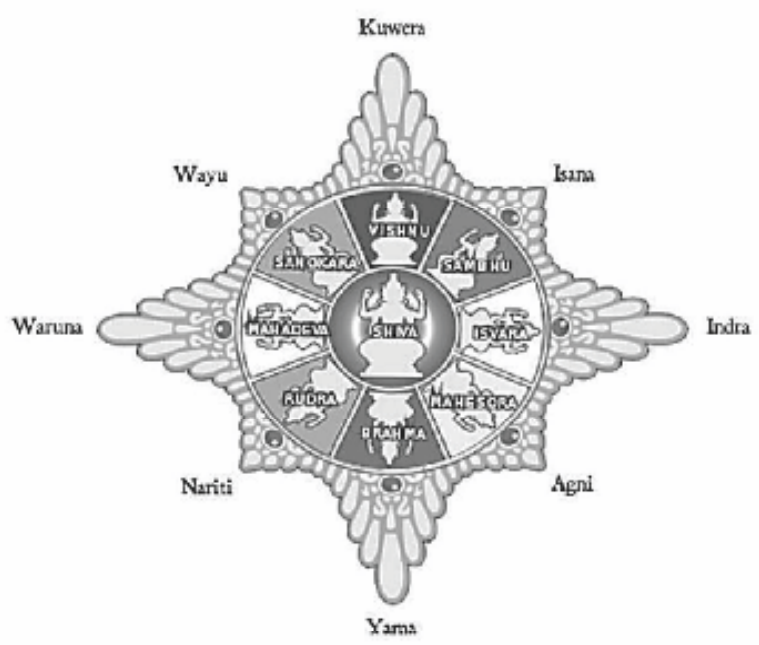

Gambar 3: Pancer Pajajaran

Beberapa lambang yang menggambarkan konsep pemisahan kekuasaan untuk kejayaan negara tersebut oleh Ir Soekarno dipadukan dengan kemajuan ilmu pengetahuan pada saat itu menjadi Penta Politica. Prinsipnya adalah ketika belajar dari peradaban bangsa lain bukan berarti menghilangkan eksistensi budaya sendiri. Itulah sebabnya, pendiri negara Republik Indonesia perlu meng-update Surya Wilwatikta sebagai kajian kearifan kejayaan peradaban Nusantara masa lalu dengan Trias Politica sebagai kemajuan ilmu pengetahuan pada saat itu menjadi bentuk baru yang cocok dalam konteks ke-Indonesiaan. Penta Politica yang dipopulerkan oleh Uttunggadewa dalam bukunya Negara Gotong Royong (2015), merupakan konsep pembagian kekuasaan yang berkepribadian bangsa Indonesia, dan diatur dalam UUD 1945. Secara skematis, hubungan antar lembaga tinggi negara dalam Penta Politica, digambarkan sebagai berikut.

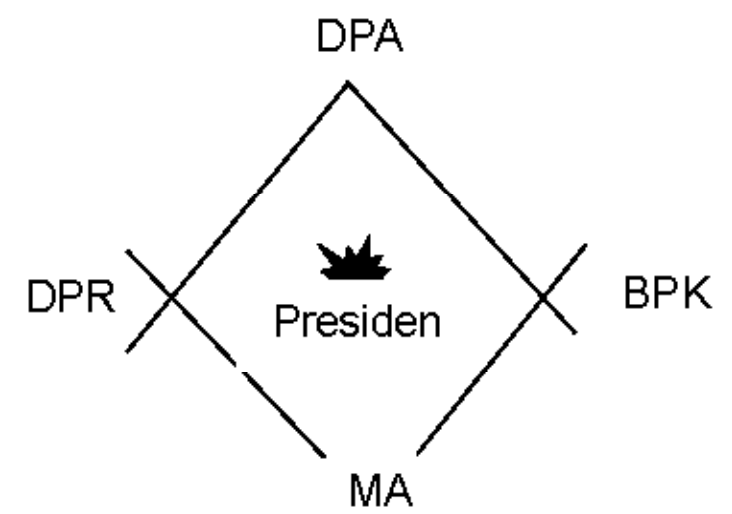

\section{Gambar 2: Penta Politika adaptasi Uttunggadewa:18}

Ploting pemisahan tugas, fungsi, dan wewenang lembaga tinggi Negara Kesatuan Republik Indonesia di era Soekarno, menempatkan Presiden sebagai pancer pelaksanan pemerintahan tertinggi di bawah MPR yang diatur berdasarkan UUD 1945. Berdasarkan UUD 1945, masingmasing lembaga tinggi negara dalam Penta Politica memiliki tugas dan fungsi sebagai berikut.

\section{Presiden, Diatur dalam UUD 1945 pasal 4-15}

Presiden sebagai pancer dalam Penta Politica adalah penyelenggara pemerintahan negara tertinggi di bawah Majelis Permusyawaratan Rakyat (MPR). Presiden bertugas menjalankan mandat yang sudah ditetapkan oleh MPR. Dengan begitu, dalam menjalankan pemerintahan negara, kekuasaan dan tanggung jawab ada di tangan Presiden. Presiden harus bekerjasama dengan DPR, tetapi Presiden tidak bertanggung jawab kepada DPR ${ }^{2}$. 


\section{Dewan Pertimbangan Agung (DPA), diatur dalam UUD 1945 pasal 16}

DPA adalah Dewan yang beranggotakan para Raja/Para Sultan dan Para Ketua Masyarakat Adat se-Nusantara yang ditunjuk untuk mewakilinya. Susunan DPA ditetapkan dengan Undang-undang Dasar. Dengan masuknya Para Raja/Sultan dan Para Ketua Adat Masyarakat dalam DPA, maka kalimat kedua dalam teks proklamasi 17 Agustus 1945 "Hal-hal yang mengenai pemindahan kekuasaan dan lain-lain diselenggarakan dengan cara seksama dan dalam waktu yang sesingkat-sesingkatnya", akhirnya telah berhasil diselenggarakan ke dalam tubuh baru dari kerajaan dan kasultanan di Nusantara bernama "Republik Indonesia". DPA berperan penting sebagai lembaga tinggi negara yang akan menjamin bahwa proses berjalannya roda pemerintahan dengan berbagai kebijakan yang dihasilkan tidak bertentangan dengan nilai-nilai keadatan dan kearifan budaya bangsa.

\section{Dewan Perwakilan Rakyat (DPR), diatur dalam UUD 1945 pasal 19—22}

Kedudukan DPR adalah sangat kuat, karena semua anggota DPR merangkap sebagai anggota MPR. DPR tidak bisa dibubarkan oleh Presiden karena memiliki kedudukan yang sejajar. DPR memiliki tugas utama di bidang perundang-undangan.

\section{Badan Pemeriksa Keuangan (BPK), diatur dalam UUD 1945, pasal 3}

BPK bertugas memeriksa pengelolaan dan tanggung jawab keuangan negara menurut UUD 1945. BPK memeriksa bagaimana pemerintah mempergunakan uang belanja negara yang sudah ditetapkan oleh MPR. Oleh karena itu, kedudukan BPK sebagai lembaga negara tidak tunduk kepada pemerintah (kekuasaan Presiden), melainkan bersifat independen dan sejajar dengan lembaga tinggi negara lainnya.

\section{Mahkamah Agung (MA), diatur dalam UUD 1945, pasal 24-25}

Mahkamah Agung merupakan lembaga negara yang memegang kekuasaan kehakiman. Kekuasaan kehakiman merupakan kekuasaan yang merdeka untuk menyelenggarakan peradilan guna menegakkan hukum dan keadilan. Mahkamah Agung adalah pengadilan tertinggi di negara, yang di bawahnya terdapat peradilan umum, peradilan agama, peradilan militer, dan peradilan tata usaha negara (PTUN).

Hubungan kelima lembaga tinggi negara berpusat pada Presiden (sebagai Pancer) selaku mandataris MPR, di mana keempat lembaga tinggi negara secara kolektif kolegial (gotong royong), memiliki fungsi sebagai berikut.

a) DPR menjalankan fungsi legislatif

b) MA menjalankan fungsi yudikatif

c) DPA menjalankan fungsi pengawasan sesuai dengan ukuran tata nilai budaya, adab, dan adat-istiadat.

d) BPK menjalankan fungsi pengawasan keuangan negara untuk menjamin terselenggaranya pasal 33 dan 34 UUD 1945.

Sementara itu, MPR sebagai penjelmaan kedaulatan rakyat merupakan lembaga tertinggi yang secara konstitusional menetapkan Undangundang Dasar (UUD), Garis-garis Besar Haluan Negara (GBHN), serta memilih Presiden dan Wakil Presiden selaku mandataris MPR. Fraksi ABRI dan Utusan Daerah termasuk utusan golongan yang mendapat hak veto dalam menjalankan kekuasaan yang berdaulat rakyat. Fraksi ABRI mempunyai hak veto apabila suatu keputusan politis dianggap membahayakan keselamatan negara, sedangkan Utusan Daerah dan Utusan Golongan/Profesi mempunyai hak veto bila kebijaksanaan pemerintah pusat tidak sesuai dengan kondisi dan kebijakan daerah dan golongan profesi.

Sesuai dengan prinsip-prinsip yang mengamanatkan terciptanya demokrasi politik dan demokrasi ekonomi, maka proses demokrasi 
politik, diejawantahkan melalui DPR yang merupakan representasi dari wakil-wakil partai politik yang dipilih melalui pemilu. Adapun demokrasi ekonomi terwujud melalui keterwakilan Utusan Daerah yang berprestasi dan berdedikasi di daerahnya, serta mampu mengoptimalkan segenap potensi yang ada di daerahnya, baik kekayaan alam, manusia, maupun potensi kulturalnya bagi kemaslahatan daerahnya. Demokrasi ekonomi juga terwujud dari Utasan Golongan yang berprestasi dan berdedikasi dalam fungsi kekaryaannya, sehingga terpilih dalam kelompok fungsionalnya secara musyawarah dan mufakat.

Dengan demikian penetapan UUD, GBHN, Presiden dan Wakil Presiden oleh MPR benar-benar dilaksanakan dengan penuh hikmat kebijaksanaan dalam permusyaratan perwakilan, tidak hanya mempertimbangkan aspek politik, melainkan juga mempertimbangkan aspek ekonomi dan budaya. Oleh karena itu, setiap produk ketetapan yang dihasilkan oleh MPR akan menjadi rujukan bagi setiap lembaga tinggi negara dalam menjalankan tugas, fungsi, dan peran, dengan penuh tanggung jawab demi terselenggaranya kedaulatan di bidang politik, kemandirian di bidang ekonomi, dan kepribadian di bidang budaya.

Dari penjelasan di atas, tampak jelas bahwa negara Indonesia tidak menerapkan pembagian kekuasaan sesuai teori Trias Politica yang dianut oleh Montesquieu di mana adanya pembagian kekuasaan berdasarkan fungsi negara, baik Legislatif, Eksekutif maupun Yudikatif, namun sejatinya Indonesia sudah memiliki Penta Politica yang cocok untuk konteks Indonesia.

Hal itu disebabkan oleh latar dan konteks Indonesia yang berbeda dengan Barat. Demokrasi Indonesia bukanlah demokrasi liberal, melainkan demokrasi yang dipimpin oleh hikmat kebijaksanaan dalam permusyawaratan/ perwakilan. Demokrasi yang mengamanatkan keterlibatan setiap warga negara untuk bergotong royong mewujudkan cita-cita proklamasi. Demokrasi yang tidak hanya ansich demokrasi politik, melainkan juga demokrasi ekonomi. Demokrasi yang tidak memberi ruang bagi munculnya feodalisme dan neo-feodalisme, melainkan demokrasi yang menempatkan kedaulatan negara ada di tangan rakyat (Soepomo, dalam sidang PPKI 1945). Demokrasi yang mensyaratkan adanya pemisahan kekuasaan antarlembaga tinggi negara dalam bentuk Penta Politica.

Akan tetapi di era Presiden Soeharto sistem ini dimandulkan, dengan cara memilih anggota fraksi ABRI dari golongan tertentu yang "Loyal" kepada Presiden Soeharto dan mengisi Utusan Daerah dan golongan justru diisi dari istri-istri para pejabat bukannya tokoh adat dan agama (Budiharjo, 2008). Fraksi ABRI, Utusan Daerah, dan Utusan Golongan/ Profesi yang seharusnya datang pada saat sidang-sidang MPR saja dan kembali kepada habitat/komunitasnya setelah sidang selesai, justru dimanjakan dengan fasilitas mewah di di Ibukota Negara terpisah dari komuntasnya. Dengan begitu, kehadirannya pada saat sidang tidak lagi mewakili kepentingan daerah/golongan profesinya (Salamah, 2017). Sistem Penta Politica di era Orde Baru sudah seiring/benar, akan tetapi pelaku dan pelaksanannya dimanipulasi. Itulah sejarah keterpurukan bangsa Indonesia di era kemerdekaan. Sebagai tata buku masa lalu, sejarah kegagalan hendaknya tidak diulangi lagi.

Apabila landasan kenegaraan dan Penta Politica dijalankan secara benar, maka implementasi cita-cita proklamasi 17 Agustus 1945, dalam Trisakti Bung Karno, yakni berdaulat secara politik, berdikari secara ekonomi, dan berkepribadian dalam kebudayaan (Trisakti) dapat diwujudkan. Dengan begitu, menjadi sangat ironis, jika para pakar dan para elit politik yang membuat tata perundangan mengabaikan warisan kekayaan intelektual kemajuan peradaban bangsa sendiri di masa lalu, dan membuat rencana pembangunan peradaban masa kini dan masa depan berdasarkan peradaban bangsa lain.

Belajar dari peradaban bangsa lain untuk mengembangkan budaya sendiri merupakan 
kewajaran, akan tetapi memiliki kepribadian sesuai dengan budaya sendiri merupakan keniscayaan yang harus dilakukan (Salamah, 2017). Dengan demikian, hasil amandemen yang dilakukan oleh Majelis Permusyawaratan Rakyat di era Reformasi, perlu ditinjau ulang relevansinya dengan landasan kenegaraan dan cita-cita Proklamasi, dengan cara pandang masa kini.

\section{PENTA POLITIKA DALAM PERSPEKTIF PERADABAN MASA KINI}

Banyak negara di dunia ini hanya memiliki Proclamation of Independence ataupun hanya memiliki Declaration of Independence. Tetapi hanya satu negara saja di dunia yang memiliki keduanya, yaitu Indonesia (Bratawijaya, 1997). Indonesia memiliki sejarah yang berbeda dengan negara-negara di dunia, karena Republik Indonesia sebelumnya berbentuk kerajaankerajaan, memiliki banyak pulau, suku bahasa, adat, agama, dan keragaman budaya.

Indonesia sebagai pewaris bangsa Nusantara, memiliki sejarah kejayaan dan keruntuhan sebagai sebuah bangsa. Sejarah kejayaan peradaban merupakan tata buku masa lalu untuk menyusun rencana pembangunan peradaban masa depan agar menjadi lebih kuat, bermartabat, dan berdaulat. Sebaliknya, sejarah keruntuhan/kemunduran peradaban masa lalu sebagai tata buku untuk menghindari keterpurukan/kehancuran bangsa di masa kini dan masa depan. Oleh karena itu, merumuskan rencana pembangunan peradaban masa depan berdasarkan peradaban bangsa lain tidak akan cocok dengan visi peradaban bangsa yang sebenarnya. Rendra (1983) menyebutnya sebagai rencana pembangunan peradaban tanpa visi.

Setiap bangsa memiliki sejarah peradaban yang berbeda dengan lainnya sebagai produk kebudayaan suatu bangsa. Teori pemilahan kekuasaan Trias Politica yang digaungkan sebagai produk teori modern Barat memang memiliki pengaruh yang sangat luas di berbagai benua pada abad XVIII-XX, baik di benua Eropa, Amerika, maupun Afro-Asia. Teori pemilahan kekuasaan yang dipelopori oleh John Locke (1690) dalam bukunya yang berjudul Two Treatises of Government, yang kemudian disempurnakan oleh Baron Secondat de Montesquieu dengan judul Spirits of the Laws (1748) itu dilatari oleh terjadinya zaman kegelapan di Eropa pada abad 15-17.

Sementara di Nusantara (leluhur bangsa Indonesia) sudah memiliki konsep pemilahan kekuasaan, di antaranya sejak abad ke-4 yang diabadikan dalam lambang prasasti Pancer Pajajaran dan Prasasti Lambang Surya Wilwatikta (Surya Majapahit) paad abad 12-13 yang diikuti oleh hampir seluruh kerajaan di wilayah Nusantara.

Penta Politica yang diatur oleh UUD 1945, telah diamanemen oleh MPR pada masa Reformasi yang dipelopori oleh Prof. Dr. H.Amien Rais selaku Ketua MPR pada masa awal reformsi tahun 1998. Perbandingan sistem pemerintahan Penta Politica dengan hasil amandemen dapat dianalisis sebagai berikut.

Hasil amandemen tersebut memiliki dampak yang cukup signifikan bagi kedaulatan politik, kemandirian ekonomi, dan kepribadian

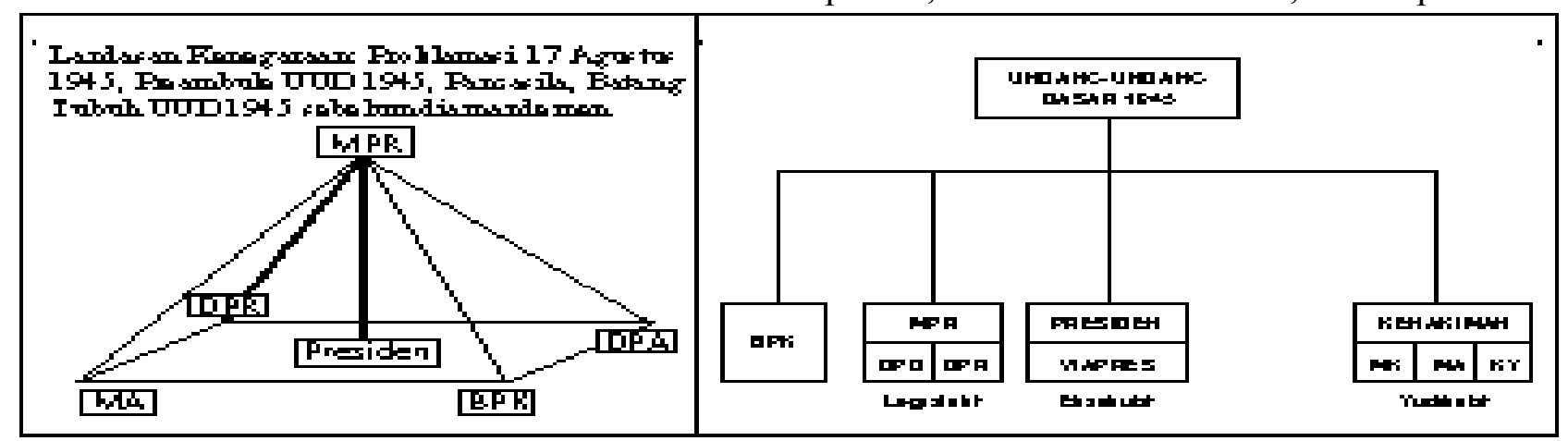


yang berkebudayaan. Hal itu disebabkan oleh sebagai berikut.

1. Hasil Amandemen telah mengeliminir beberapa landasan kenegaraan dalam Penta Politica dalam menjalankan sistem pemerintahan, yakni Teks Proklamasi 1945, Preambule UUD 1945, Pancasila, dan Batang Tubuh UUD 1945, menjadi hanya berlandaskan pada UUD 1945. Amputasi atau eleminir terhadap landasan kenegaraan lainnya dalam pelaksanaan sistem pemerintahan, berdampak pada makin menjauhkan tata perundangan dan peraturan yang dihasilkan oleh DPR jauh dari landasan kenegaraan yang dicita-citakan dalam proklamasi 17 Agustus 1945, KeBhinneka-an yang menjadi pancer Pancasila, dan Preambule UUD 1945.

2. Hasil Amandemen telah menghilangkan peran DPA dalam Penta Politica yang beranggotakan para Sultan/Raja, para ketua dan pemangku adat yang ada di wilayah nusantara, sehingga kebijakankebijakan, peraturan, dan perundangan yang dihasilkan oleh DPR dan Presiden tidak memiliki pertimbangan budaya bangsa. Pengamputasian peran DPA, hanya didasarkan dengan kasus di zaman kekuasaan Orde Baru, yakni DPA dimandulkan fungsinya dan diisi oleh para istri pejabat dan orang-orang yang "Dianggap loyal" kepada presiden Soeharto. Seharusnya DPA tidak diamputasi tetapi difungsikan kembali sesuai dengan tujuan pada landasan kenegaraan. Pengamputasian peran DPA telah menghilangkan fungsi kesejarahan landasan kenegaraan, khususnya yang tercantum pada Teks Proklamasi Kemerdekaan, yakni "Halhal yang mengenai pemindahan kekuasaan dan lain-lain diselenggarakan dengan cara seksama dan dalam waktu yang sesingkatsesingkatnya". Teks tersebut merupakan proses peralihan kekuasaan dari kerajaan/ kasultanan menjadi bentuk baru bernama "Republik Indonesia". Itulah sebabnya, peran DPA menjadi sangat penting sebagai lembaga tinggi negara yang menjamin bahwa proses berjalannya roda pemerintahan dengan berbagai kebijakan yang dihasilkan tidak bertentangan dengan nilai-nilai keadatan dan kearifan budaya bangsa. Hilangnya peran DPA menimbulkan dampak bagi bangsa Indonesia, yakni menjadi makin kehilangan jati diri sebagai bangsa yang berdaulat atau berkepribadian dalam budaya.

3. Hasil amandemen telah mengubah peran, fungsi, tugas, dan wewenang MPR sebagai lembaga tertinggi menjadi lembaga tinggi negara, sehingga MPR tidak lagi memberikan mandat kepada Presiden, tidak membuat UUD, tidak berwewenang membuat GBHN, dan juga berwewenang memberhentikan Presiden dan wakil Presiden.

4. Hasil amandemen telah mengubah komposisi anggota MPR yang mengakomdasi kedaulatan ekonomi kerakyatan, yakni dengan melibatkannya Utusan Daerah (berupa pelopor yang peka dan berdedikasi membangun daerahnya) dan Utusan Golongan/Profesi (berupa pelopor yang peka dan berdedikasi memajukan profesi di komunitasnya) diamputasi dan digantikan dengan DPD. Utusan Daerah dan Utusan Golongan/Profesi yang sebelumnya hanya datang setahun sekali mengikuti sidang MPR dalam penyusunan dan pengawasan Undang-undang Dasar dan GBHN yang berdaulat rakyat, dan kembali ke habitat/ komunitasnya setelah sidang selesai, diganti dengan DPD yang dimenaragadingkan di Jakarta, sehingga tidak mengetahui masalah riel yang dibutuhkan daerah dan golongan profesi yang diwakilinya.

5. Hasil amandemen telah mengubah peran DPD semakin dikerdilkan karena secara 
riil memang tidak mewakili pengembangan potensi daerah dan profesi. Hilangnya peran Utusan Daerah dan Utusan Golongan yang diganti dengan DPD berdampak pada kekuatan demokrasi ekonomi tidak dapat diejawantahkan/diwujudkan dalam bentuk ekonomi kerakyatan. Pembangunan ekonomi tidak berdasarkan kedaulatan rakyat atau tidak berdaulat rakyat. Ini bertentangan dengan landasan kenegaraan yang tertuang dalam Preambule UUD 1945, alenea 4 dan UUD 1945 pasal 33 dan 34 sebelum diamandemen, sulit diwujudkan karena tidak ada keterwakilan kedaulatan rakyat dalam tubuh MPR.

6. Hasil amandemen menambah peran, tugas, dan wewenang DPR, sehingga dominasi peran eksekutif (Presiden pada masa Orde Baru) bergeser ke dominasi peran legislatif pada masa Orde Reformasi. Kedaulatan bergeser dari kedaulatan presiden ke kedaulatan DPR atau daulat partai. Sementara kedaulatan rakyat di bidang politik tidak terakomodasi melalui peran DPR, karena fungsi dan wewenang yang terlalu luas untuk kepentingan kelompok dan partainya. Sebelum diamandemen hubungan Penta Politica dengan MPR sesuai dengan jiwa gotong royong dalam mengemban amanat rakyat yang tertuang dalam landasan kenegaraan. Tugas masing-masing jelas dan tidak ada tumpang tindih. Namun setelah diamanemen, tugas lembaga tinggi negara menjadi tumpang tindih, sebagai akibat dominasi peran dan fungsi DPR yang seharusnya sebagian diemban oleh MPR, DPA, BPK, dan MA.

Tampaknya amandemen terhadap UUD 1945 akan dilakukan secara terus-menerus (saat ini sudah lima kali). Tanpa pemahaman yang benar terhadap landasan kenegaraan dalam perspektif sejarah sebagai tolak ukur, hasil amandemen akan berdampak fatal bagi kedaulatan negara secara politik, kemandirian bangsa secara ekonomi, dan jati diri dalam berkebudayaan. Terlebih jika pelaku amandemen pada umumnya sudah "Terjangkit virus" pragmatisme politik.

Perlu dievaluasi, apakah hasil amandemen UUD 1945 telah mampu mewujudkan citacita kemerdekaan sebagaimana yang tertuang dalam prembul UUD 1945 yang tertulis "Bahwa sesungguhnya kemerdekaan itu ialah hak segala bangsa" tersebut telah dirasakan oleh segenap bangsa Indonesia? Faktanya, sampai saat ini, sebagian besar bangsa Indonesia masih terjajah secara pola fikir, budaya, dan ekonomi. Pendapat ini terlihat dari fakta yang terjadi dalam kehidupan bermasyarakat, berbanding terbalik dengan rumusan yang tertuang dalam pembukaan Undang-Undang Dasar 1945.

Akankah amandemen UUD 1945 perlu dilanjutkan atau ditinjau kembali kesesuaiannya dengan landasan kenegaraan bangsa Indonesia? Pernah dimunculkan wacana unttuk mengembalikan amandemen kepada UUD 1945 yang asli, namun caranya yang keliru. Peninjauan kembali hasil amandemen bukan dengan cara meng-empeach presiden, karena Presiden tidak memiliki wewenang untuk mengamandemen UUD 1945. Peninjauan kembali akan lebih bijak apabila Pelaku sejarah amandemen UUD 1945 saat ini masih hidup, dihadirkan sebagai saksi sejarah terjadinya amandemen dalam tinjauan kerelevansian hasil amandemen dengan landasan kenegaraan dan cita-cita proklamasi 17 Agustus 1945. Perlu dihadirkan pula saksi ahli yang terdiri atas para arkheolog, antropolog, budayawan, sejarawan, para raja dan para sultan, para pemuka adat, ahli tata negara, ahli hukum yang benarbenar memahami substansi landasan kenegaraan dan Penta Politica sebagai pembahas dalam meninjau kerelevansian hasil amandemen agar bangsa Indonesia tidak semakin kehilangan arah dalam pembangunan ekonomi dan berdemokrasi, serta tidak kehilangan jati diri, sebagai bangsa yang berperadaban maju. 


\section{KESIMPULAN}

Di zaman Kejayaan Kerajaan Nusantara, seorang Raja sebagai pancer pelaksanan pemerinatahn selalu didampingi oleh Pujangga dan mahapatihnya, karena seorang pujangga ibarat roh, dan seorang raja ibarat badan. Segala peraturan dan kebijakan raja diukur dari kebaikan dan kebermaslahatan bagi rakyat dan negara. Bangsa yang besar adalah bangsa yang menghargai sejarah. Pendiri bangsa telah membuat landasan kenegaraan dan sitem pemerintahan dalam bentuk Penta Politica. Presiden sebagai Pancer pelaksanan pemerintahan bersama lembaga tinggi negara lainnya (DPA, DPR, BPK, dan MA) bergotong royong membangun peradaban bangsa di masa depan menjadi bangsa yang makmur, sejahtera, kuat, bermartabat, dan berdaulat, secara ekonomi, politik, dan kebudayaan. MPR sebagai penjilmaan kedaulatan rakyat merupakan lembaga tertinggi yang secara konstitusional menetapkan Undang-undang Dasar (UUD), Garis-garis Besar Haluan Negara (GBHN), serta memilih Presiden dan Wakil Presiden selaku mandataruis MPR.

\section{DAFTAR RUJUKAN}

Bratawijaya, T. W. (1997). Mengungkap dan Mengenal Budaya Jawa. Jakarta: PT Pradnya Paramita.

Budiharjo, M. (2008). Dasar- Dasar Ilmu Politik. Jakarta: Gramedia Pustaka Utama.

Busroh, A. D. (2010). Ilmu Negara. Jakarta: Bumi Aksara.

Djarot, E. (2006). Siapa Sebenarnya Soeharto! Fakta dan Kesaksian para Pelaku Sejarah G-30-S. Jakarta: Media Kita.

Hendrawan, L. (2014). SUNDA - (Pikukuh Kenegaraan, Kebangsaan, Kemasyarakatan, \& Kemanusiaan).

Kartakusuma, R. (1991). Anekaragam Bahasa Prasastidi Jawa Barat Pada Abad Ke-5 Masehi sampai Ke-16 Masehi: Suatu Kajian Tentang Munculnya Bahasa Sunda.
Universitas Indonesia.

Rendra, W. . (1983). Mempertimbangkan Tradisi. Jakarta: Gramedia.

Salamah, U. (2017). Hegemonik Tanding Tirto Aji. Malang: MNC Press. 